\title{
Industry Influences On Organizational Slack
}

\author{
Dan Marlin, University of South Florida St. Petersburg, USA
}

\begin{abstract}
The purpose of this study is to identify and examine differences in organizational slack across multiple industries. Using a sample of 353 US publicly traded firms, eight measures of organizational slack were examined across six 2-digit SIC industry groupings. The author's analyses revealed significant differences across industries in each of the slack measures examined. Implications and areas for future research are discussed.
\end{abstract}

Keywords: Organizational Slack; Available Slack; Recoverable Slack; Potential Slack; Industry

\section{INTRODUCTION}

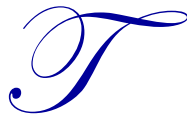

he topic of organizational slack resources has received - and continues to receive - a great deal of attention in the literature (Chen, Yang \& Lin, 2013; Cheng \& Kesner, 1997; Chiu \& Liaw, 2009; Daniel et al., 2004; Greenley \& Okemgil, 1998; Palmer \& Wiseman, 1999). Slack can be defined as the resources in or available to an organization that are in excess of the minimum necessary to produce a given level of organizational output (Cyert \& March, 1963; Nohria \& Gulati, 1996). There are both internal and external components of slack. Resources that are within the firm, either readily available or already absorbed, can be considered internal slack while resources that are not currently within the firm, such as the availability of debt financing, can be considered external slack.

Research on organizational slack consists of two major research streams - the slack and performance relationship and the slack and innovation relationship. Slack has been argued to be a benefit because of its ability to buffer firms from shortages of funds as well as its potential to foster innovation (Bourgeois, 1981; Cyert \& March, 1963). It has also been argued, however, that organizational slack is wasteful, inefficient, and accumulates due to the self-serving interests of managers (Jensen \& Meckling, 1976; Nohria \& Gulati, 1996). These arguments are based on the notion that slack has either positive or negative impact on firm outcomes. Other research has hypothesized contingency (Geiger \& Makri, 2006) or curvilinear (Nohria \& Gulati, 1996) relationships between slack and firm outcomes. In aggregate, however, research on slack and firm outcomes remains largely equivocal (for a relatively recent meta-analysis and review, see Daniel et al., 2004). Further, when considering these relationships, questions arise as to whether - and to what extent - slack resources vary across industries. To date, there is little research specifically focusing on differences in various types of slack across industries (see Wefald et al., 2010 for an exception).

The purpose of this study is to identify and examine differences in organizational slack across multiple industries. More specifically, using a sample of 353 US publicly traded firms, eight measures of organizational slack were examined across six 2-digit SIC industry groupings within the manufacturing sector. In the next section, a brief overview of research on different types of slack is presented. Next, the methodology is described and the results of the analyses are presented. Finally, implications and future research areas are discussed.

\section{LITERATURE REVIEW}

Previous research suggests the existence of multiple components of slack (Bourgeois, 1981; Bourgeois \& Singh, 1983; Geiger \& Cashen, 2002; Singh, 1986). These components have been categorized as available, recoverable, and potential slack (Bourgeois, 1981; Bourgeois \& Singh, 1983), absorbed and unabsorbed slack (Singh, 1986), or internal and external slack (Geiger \& Cashen, 2002). These categorization approaches are similar in that internal slack is within the firm and either readily available and unabsorbed or already absorbed and 
considered recoverable, while slack resources that are external - and thus not within the firm - are considered potential or unabsorbed. Given the consistency across these frameworks, the author utilized available, recoverable, and potential slack (i.e., Bourgeois, 1981; Bourgeois \& Singh, 1983) in this study.

Available slack has been measured in previous studies using variables such as the current ratio (current assets/current liabilities) of the firm (Bourgeois \& Singh, 1983; Bromiley, 1991; Cheng \& Kesner, 1997). This component of slack serves to capture the extent to which firms have resources that are untapped, but readily available. It has been argued that available slack provides a pool of resources that reduces the impact of external threats and fosters experimentation within the firm (Bourgeois, 1981; Cyert \& March, 1963). Because available slack exists within the organization, managers should be more likely to pursue projects with promising outcomes (Cyert \& March, 1963).

Recoverable slack has been operationalized in previous studies using variables such as selling and general administrative expenses divided by firm sales (Bourgeois \& Singh, 1983; Bromiley, 1991). This component of slack serves to capture the extent to which resources are embedded in the firm as excess costs, but could be recovered when firms experience financial difficulty (Bourgeois \& Singh, 1983). This type of slack has also been referred to as absorbed slack (Singh, 1986). Recoverable, or absorbed slack, can best be thought of as resources that are absorbed into the firm in the form of expenses which are greater than those needed by the firm. For example, firms may employ more individuals than necessary to operate effectively year round which can provide a cushion or buffer from disruptions in output (Cyert \& March, 1963).

The last component - potential slack - has been operationalized using variables such as a firm's debt-toequity ratio (Bourgeois \& Singh, 1983; Bromiley, 1991; Palmer \& Wiseman, 1999). This measure represents the ability of a firm to secure resources with the use of debt financing. It could be expected that as potential slack increases, experimentation is encouraged (Geiger \& Cashen, 2002). This is attributable to the resources potentially available which allow for less anxiety and concern about the risks of research and development and short-term performance issues.

\section{METHODOLOGY}

\section{Sample and Data Collection}

The starting sample included manufacturing firms (SIC 2000-3999) in the S\&P 500, S\&P MidCap 400, and S\&P SmallCap 600 Indices for the year 2010. From this sample, only firms in six major 2-digit SIC code groupings or industry divisions were chosen: 20 - Food and Kindred Products, 28 - Chemicals and Allied Products, 35 Industrial and Commercial Machinery and Computer Equipment, 36 - Electronic and Other Electrical Equipment and Components, Except Computer Equipment, 37 - Transportation Equipment, and 38 - Measuring, Analyzing, and Controlling Instruments; Photographic, Medical and Optical Goods; Watches and Clocks. The year 2010 was chosen as a recent time frame to examine the relationships of interest. The final sample consisted of 353 firms.

\section{Slack Measures}

A total of eight measures were utilized to capture available, recoverable, and potential slack (Bergh \& Lawless, 1998; Bourgeois \& Singh, 1983; Bromiley, 1991; Cheng \& Kesner, 1997; Daniels et al., 2004; Geiger \& Cashen, 2002; Palmer \& Wiseman, 1999). Available slack was operationalized using three measures - current ratio, quick ratio, and working capital. Current ratio was derived using current assets divided by current liabilities. Quick ratio was calculated as current assets minus inventories divided by current liabilities. Working capital was calculated as current assets minus current liabilities divided by sales. Potential slack was operationalized using three ratio measures - debt to equity, debt to sales, and debt to assets. Recoverable slack was operationalized as SGA expenses or selling, general, and administrative expenses divided by sales and R\&D intensity or research and development expenses divided by sales. 


\section{Analysis}

Data from the 353 firms sampled were analyzed using ANOVA and pairwise means comparisons. ANOVA was used to test for significant differences in the eight slack measures across the six industry groupings examined. Pairwise means comparisons were then used to identify the specific differences that existed and their direction.

Table 1: Variable Means and Tests for Between Industry Differences in Slack

\begin{tabular}{|c|c|c|c|c|c|c|c|c|}
\hline \multicolumn{9}{|c|}{ 2-Digit SIC Industry $^{\mathbf{a}}$} \\
\hline Variable & $\mathbf{2 0}$ & $\mathbf{2 8}$ & $\mathbf{3 5}$ & $\mathbf{3 6}$ & $\mathbf{3 7}$ & $\mathbf{3 8}$ & $\mathbf{F}$ & Means Comparisons* $^{*}$ \\
\hline Available Slack & & & & & & & & \\
\hline Current Ratio & 1.881 & 2.793 & 2.779 & 3.794 & 2.388 & 3.793 & $7.54 * * *$ & $36,38>28,35,37,20 ; 28,35>20$ \\
\hline Quick ratio & 1.113 & 2.171 & 2.109 & 3.140 & 1.680 & 2.931 & $8.80 * * *$ & $36,38>28,35,37,20 ; 28,35>20$ \\
\hline Working Capital & .113 & .361 & .438 & .536 & .249 & .535 & $8.88 * * *$ & $36,38>28,37,20 ; 35>37,20 ; 28>20$ \\
\hline Potential Slack & & & & & & & & \\
\hline Debt/Equity & 1.036 & .607 & .389 & .337 & .698 & .322 & $3.87 * *$ & $20>28,35,36,38$ \\
\hline Debt/Sales & .281 & .270 & .158 & .157 & .176 & .233 & $4.73 * * *$ & $20,28>37,35,36$ \\
\hline Debt/Assets & .293 & .199 & .133 & .115 & .172 & .150 & $9.14 * * *$ & $20>28,37,38,35,36 ; 28>35,36$ \\
\hline Recoverable Slack $^{\mathrm{b}}$ & & & & & & & & \\
\hline SGA Expenses & .187 & .327 & .292 & .306 & .133 & .380 & $12.48 * * *$ & $38,28,36,35>20,37 ; 38>36,35$ \\
\hline R\&D Intensity & .007 & .084 & .060 & .114 & .037 & .078 & $12.01 * * *$ & $36>28,38,35,37>20 ; 28,38>37$ \\
\hline$N$ & 20 & 71 & 70 & 94 & 23 & 75 & 353 & \\
\hline
\end{tabular}

${ }^{\mathrm{a}} 20$ - Food and Kindred Products, 28 - Chemicals and Allied Products, 35 - Industrial and Commercial Machinery and Computer Equipment, 36 Electronic and Other Electrical Equipment and Components, Except Computer Equipment, 37 - Transportation Equipment, and 38 - Measuring, Analyzing, and Controlling Instruments; Photographic, Medical and Optical Goods; Watches and Clocks. ${ }^{b}$ Lower values indicate higher slack. $+\mathrm{p}<.10 ; * * \mathrm{p}<.01 ; * * * \mathrm{p}<.001$

\section{RESULTS}

Variable means and tests for differences in organizational slack across the six industry groupings are presented in Table 1. Significant overall effects $(\mathrm{p}<.010$ to $\mathrm{p}<.001)$ and between industry differences $(\mathrm{p}<.05)$ using pairwise means comparisons were found for all eight slack measures. More specifically, firms in 2-digit SIC industry groupings 36 (Electronic and Other Electrical Equipment and Components, Except Computer Equipment) and 38 (Measuring, Analyzing, and Controlling Instruments; Photographic, Medical and Optical Goods; Watches and Clocks) had very similar slack profiles with higher overall levels of all three types of slack while firms in 2-digit SIC industry grouping 20 (Food and Kindred Products) had lower overall levels of all three types of slack. Concerning similarities across industries, firms in 2-digit SIC industry groupings 28 (Chemicals and Allied Products) and 35 (Industrial and Commercial Machinery and Computer Equipment) both had moderate levels of available slack along with relatively high levels of recoverable slack; firms in 2-digit SIC industry groupings 28 and 37 (Transportation Equipment) had similar moderate levels potential slack; firms in 2-digit SIC industry groupings 35, 36, and 38 had similar lower levels of potential slack; and firms in 2-digit SIC industry groupings 20 and 37 had similar low levels of recoverable slack. In total, these results suggest important differences and similarities in organizational slack across the industries examined.

\section{DISCUSSION AND CONCLUSIONS}

The purpose of this study was to identify and examine organizational slack differences across multiple manufacturing industries. More specifically, using a sample of 353 US publicly traded firms in the year 2010, multiple measures of organizational slack were examined across six major 2-digit SIC code industry groupings. The results of the analyses reveal significant differences in each of eight slack measures across the industry groupings examined. Implications of these results and areas for future research are discussed below.

The findings of this study highlight the potentially important role of industry on levels of organizational slack. Of particular interest are the findings that levels of slack can vary significantly from industry to industry even among manufacturing firms. More specifically, the results of this study indicate multiple differences along each slack measure across the six industry groupings examined. The greatest differences existed between industry groupings 36 and 20 with the former having the highest overall levels of slack and the latter having the lowest 
overall levels of slack. Also of interest is that the levels of the different types of slack varied significantly, both within and between industries. That is, while some industries tended to be higher (or lower) in all types of slack, other industries were mixed having relatively higher levels of one type of slack and relatively lower levels of another. Finally, it should be noted that similarities were also found with the greatest ones existing between industry groups 36 and 38 .

Like most research efforts the current study has limitations that provide opportunities for future research. First, a limitation of the study involves the use of cross-sectional data. Future research in this area would benefit from using longitudinal data and from examining changes in slack over time. A second limitation involves the limited number of organizational slack measures examined. Future researchers may benefit from including additional indicators as well as examining a broader range of industries such as services, retailers, or financial organizations. Finally, the author did not test for causality in the current study. Future research would benefit from the examination of the relationship between slack and firm outcomes like innovation and performance. Overall, it is hoped that this study will provide an important contribution to the organizational slack literature.

\section{AUTHOR INFORMATION}

Dan Marlin is an Associate Professor of Management at the University of South Florida St. Petersburg. His research has been published in journals such as Nonprofit Management and Leadership, Journal of Managerial Issues, Strategic Management Journal, Health Services Research, and Health Care Management Review. E-mail: marlind@usfsp.edu

\section{REFERENCES}

1. Bergh, D., \& Lawless, M. (1998). Portfolio restructuring and limits to hierarchical governance: The effects of environmental uncertainty and diversification strategy. Organization Science, 9, 87-102.

2. Bourgeois, L. J. (1981). On the measurement of organizational slack. Academy of Management Review, 6 , 29-39.

3. Bourgeois, L. J., \& Singh, J. V. (1983). Organizational slack and political behavior within top management groups. Academy of Management Proceedings, 43-47.

4. Bromiley, P. (1991). Testing a causal model of corporate risk taking and performance. Academy of Management Journal, 34, 37-59.

5. Chen, Y., Yang, D., \& Lin, F. (2013). Does technological diversification matter to firm performance? The moderating role of organizational slack. Journal of Business Research, 66, 1970-1975.

6. Cheng, J., \& Kesner, I. (1997). Organizational slack and response to environmental shifts: The impact of resource allocation patterns. Journal of Management, 23, 1-18.

7. Chiu, Y., \& Liaw, Y. (1999). Organizational slack: Is more or less better? Journal of Organizational Change Management, 22, 321-342.

8. Cyert, R. M., \& March, J. G. (1963). A Behavioral Theory of the Firm. Englewood Cliffs, NJ: PrenticeHall,

9. Daniel, F., Lohrke, F. T., Fornaciari, C. J., \& Turner, R. A. (2004). Slack resource and firm performance: A meta-analysis. Journal of Business Research, 57, 565-574.

10. Geiger, S. W., \& Cashen, L. H. (2002). A multidimensional examination of slack and its impact on innovation. Journal of Managerial Issues, 14, 68-84.

11. Geiger, S. W., \& Makri, M. (2006). Exploration and exploitation innovation processes: The role of organizational slack in R\&D intensive firms. Journal of High Technology Management Research, 17, 97 108.

12. Greenley, G. E., \& Oktemgil, M. (1998). A comparison of slack resources in high and low performing British companies. Journal of Management Studies, 35, 377-398.

13. Jensen, M. C., \& Meckling, W. H. (1976). Theory of the firm: Managerial behavior, agency cost, and ownership structure. Journal of Financial Economics, 3, 305-360.

14. Nohria, N., \& Gulati, R. (1996). Is slack good or bad for innovation? Academy of Management Journal, 39, 1245-1264. 
15. Palmer, T. B., \& Wiseman, R. M. (1999). Decoupling risk taking from income stream uncertainty: A holistic model of risk. Strategic Management Journal, 20, 1037-1062.

16. Singh, J. V. (1986). Performance, slack and risk-taking in organizational decision making. Academy of Management Journal, 29, 562-585.

17. Wefald, A. J., Katz, J. P., Downey, R. G., \& Rust, K. G. (2010). Organizational slack, firm performance, and the role of industry. Journal of Managerial Issues, 22, 70-87. 


\section{NOTES}

